\title{
PEMBERDAYAAN MASYARAKAT DALAM PEMANFAATAN LIMBAH PERTANIAN SEBAGAI BIOENERGI ALTERNATIF, MEDIA TANAM, DAN PUPUK ORGANIK
}

\author{
Fatwa Tentama \\ Fakultas Psikologi Universitas Ahmad Dahlan Yogyakarta \\ fatwa.tentama@psy.uad.ac.id \\ Muchsin Maulana \\ Fakultas Kesehatan Masyarakat Universitas Ahmad Dahlan Yogyakarta \\ muchsin.maulana@ikm.uad.ac.id \\ Rini Anggraeni \\ Fakultas Pertanian Universitas Janabadra \\ ri_nies@yahoo.co.id
}

\begin{abstract}
ABSTRAK
Wilayah Ngemplak Sleman merupakan penghasil padi yang berlimpah yang menghasilkan banyak limbah sekam padi. Masyarakat petani belum mampu memanfaatkan sekam padi yang berlimpah karena minimnya kesadaran, pengetahuan dan ketrampilan dalam memanfaatkannya. Program ini dilaksanankan untuk dengan tujuan memanfaatkan sekam padi menjadi briket bioarang, media tanam, dan pupuk organik. Mitra IbM yaitu 2 kelompok tani di Bimomartani, Ngemplak Sleman. Metode pendekatan untuk mengatasi limbah sekam padi adalah pemberdayaan kelompok tani untuk memanfaatkan sekam padi menjadi briket bioarang, media tanam, dan pupuk organik. Hasil dari program ini adalah solusi penanggulangan pencemaran lingkungan, produk dari limbah sekam padi, dan pemberdayaan masyarakat mengolah limbah sekam.
\end{abstract}

Kata kunci: briket bioarang, media tanam, pupuk organik, sekam padi

\begin{abstract}
Ngemplak region Sleman an abundant producer of rice that produce a lot of waste rice husk. Farming communities have not been able to take advantage of the abundant rice husks due to lack of awareness, knowledge and skills in use. The program was implemented for the purpose utilize rice husks into briquettes bioarang, planting media, and organic fertilizers. Partners IbM is 2 farmer groups in Bimomartani, Ngemplak Sleman. Method approach to dealing with the waste rice husk is the empowerment of farmer groups to utilize rice husks into briquettes bioarang, planting media, and organic fertilizers. The
\end{abstract}


results of this program is the solution of environmental pollution prevention, waste product from rice husks, and empowerment process waste husks

Keyword : briquette bioarang, planting media, organic fertilizers, rice husks

\section{PENDAHULUAN}

Kabupaten Sleman merupakan wilayah dengan luas lahan pertanian terbesar di Propinsi Daerah Istimewa Yogyakarta. Total luas lahan pertanian di wilayah Sleman adalah 39.462 (Dinas Pertanian Kab./Kota, Provinsi D.I.Yogyakarta, 2010). Setiap musim bertanam dan musim panen padi lahan-lahan pertanian di Kabupaten Sleman tersebut akan akan dihasilkan padi kering giling berlimpah termasuk kecamatan Ngemplak yang yang menjadi lokasi kegiatan pengabdian masyarakat ini.

Pada setiap penggilingan padi akan terlihat tumpukan bahkan gunungan sekam padi yang semakin berlimpah. Hsu dan Luh (1980) menjelaskan pada proses penggilingan padi, sekam akan terpisah dari butir beras dan menjadi bahan sisa atau limbah penggilingan. Dibutuhkan tempat penyimpanan sekam padi yang luas sehingga biasanya sekam padi dibakar untuk mengurangi volumenya. Saat ini pemanfaatan sekam padi tersebut masih sangat terbatas, sehingga sekam padi tetap menjadi bahan limbah yang mengganggu lingkungan. Masyarakat petani belum mampu memanfaatkan sekam padi tersebut karena minimnya kesadaran, pengetahuan dan ketrampilan untuk memanfaatkannya. Pencemaran lingkungan karena sekam padi tidak dapat dihindari sehingga harus dicarikan jalan keluar untuk permasalahan ini. Sekam adalah bagian terluar dari butir padi yang merupakan hasil samping saat proses penggilingan padi. Pada proses penggilingan padi, sekam akan terpisah dari butir beras dan menjadi bahan sisa atau limbah penggilingan. Kadar sekam adalah 20 - 30\% dari bobot gabah yang digiling, dedak/abu $15 \%$, dan beras giling 50 53,5\% (Hambali dkk., 2007).

Limbah sekam padi banyak terdapat di daerah pedesaan dengan mayoritas masyarakatnya sebagai petani dan salah satu wilayah di Kabupaten Sleman yang mempunyai produksi padi dan permasalahan limbah sekam yang tinggi yaitu Desa Bimomartani, Ngemplak Sleman. Mitra IbM yaitu kelompok petani yang terdiri dari 2 kelompok tani di Bimomartani, Ngemplak Sleman.

Permasalahan khusus yang dihadapi oleh mitra petani belum memperlakukan sekam padi sebagai bahan yang bermanfaat dan sebaliknya menjadi bahan limbah yang mencemari lingkungan sekitar karena saat ini sekam hasil penggilingan padi yang berlimpah itu banyak yang dibuang begitu saja atau hanya dibakar. Akibatnya hasil dari pembakaran tersebut, yaitu karbon sangat membahayakan bagi lingkungan dan manusia. Padahal sekam sangat berpotensi sebagai sumber bahan baku energi alternatif yang murah bagi masyarakat (Hambali dkk., 2007). 
Pemanfaatan sekam padi menjadi briket bioarang, media tanam, dan pupuk organik akan dapat meminimalisasi pencemaran limbah sekam padi pada lingkungan persawahan dan memperkuat perekonomian keluarga. Melalui proses yang sederhana, tanpa membutuhkan alat yang canggih dan bahan baku yang melimpah, para petani dapat membuat sendiri briket bioarang, media tanam, dan pupuk organik dari sekam padi. Sekam yang selama ini kurang bermanfaat dapat menjadi produk yang bermanfaat dan memiliki nilai jual yang dapat menguatkan perekonomian. Kurniawan dan Marsono (2008) mengatakan sekam tersebut dengan cara diolah melalui beberapa proses yang bisa digunakan sebagai alternatif bahan bakar untuk keperluan memasak sehingga menghemat pengeluaran sehari-hari. Briket bioarang memiliki keunggulan yaitu mudah dinyalakan meskipun basah, jumlah asap yanng dihasilkan sedikit, dan tidak perlu ditunggu terus menerus selama penggunaannya. Hambali, Mujdalipah, Tambunan, Pattiwiri, dan Hendroko (2008) menambahkan bahwa bahan bakar briket bioarang lebih ramah lingkungan karena tidak mengandung zat beracun yang dapat mencemari udara.

Sekam dapat dimanfaatkan sebagai media tanam dan pupuk organik yang lebih murah (Wuryaningsih dan Darliah, 1994). Arang sekam padi dapat digunakan sebagai campuran pupuk kandang. Arang sekam padi dapat digunakan sebagai campuran pupuk kandang. Trisnadi (2016) menemukan bahwa arang sekam juga berfungsi meningkatkan cadangan air tanah juga terjadinya peningkatan kadar pertukaran kalium (K) dan magnesium (Mg). Arang sekam atau sekam bakar juga memiliki kandungan tinggi unsur silikat (Si) dan magnesium (Mg) tetapi rendah pada kandungan kalsium (Ca). Bahan organik yang mempunyai sifat remah sehingga udara, air, dan akar mudah masuk dalam fraksi tanah dan dapat mengikat air. Hal ini sangat penting bagi akar bibit tanaman karena media tumbuh sangat berkaitan dengan pertumbuhan akar atau sifat di perakaran tanaman (Putri 2008). Kusmarwiyah dan Erni (2011) menyatakan bahwa media tanah yang ditambah arang sekam dapat memperbaiki porositas media sehingga baik untuk respirasi akar, dapat mempertahankan kelembaban tanah, karena apabila arang sekam ditambahkan ke dalam tanah akan dapat mengikat air, kemudian dilepaskan ke pori mikro untuk diserap oleh tanaman dan mendorong pertumbuhan mikroorganisme yang berguna bagi tanah dan tanaman. Sukaryorini dan Arifin (2007) juga menyampaikan bahwa arang sekam mampu memberikan respons yang lebih baik terhadap berat basah tanaman maupun berat kering tanaman.

Persemaian yang menggunakan arang sekam padi sebagai pupuk dasar memiliki beberapa keuntungan yaitu tanah menjadi gembur, sehingga bibit mudah dicabut dan mengurangi akar yang putus pada saat percabutan. Arang dapat juga digunakan sebagai pupuk dasar untuk menanam padi di sawah, yaitu diberikan bersamaan pupuk kandang kira-kira 1 minggu sebelum tanam. Arang sekam padi sebagai pupuk organik sangat bermanfaat untuk meningkatkan kesuburan tanah dan memperbaiki struktur tanah (Jumena, 2009). 
Tujuan dari pengabdian ini adalah memanfaatkan limbah sekam padi menjadi briket bioarang untuk mengurangi penggunaan bahan bakar fosil ketika memasak, penyediaan media tanam dan persemaian padi, serta penyediaan pupuk organik.

\section{METODE}

Pengabdian ini dilakukan pada kelompok tani di Desa Bimomartani kecamatan Ngemplak, Sleman Yogyakarta. Mitra IbM yaitu 2 kelompok tani di Bimomartani, Ngemplak Sleman. Metode pelaksanaan yang ditawarkan untuk mengatasi permasalahan pencemaran limbah sekam padi adalah pelatihan untuk memanfaatkan sekam padi menjadi briket bioarang, media tanam, dan pupuk organik.

Pemberdayaan masyarakat diinisiasi dengan pelatihan tentang "Budaya Sadar Lingkungan dan Motivasi Berwirausaha", pelatihan pembuatan briket bioarang sebagai bahan bakar alternatif, pelatihan pemanfaatan briket bioarang untuk keperluan memasak sehari hari, pelatihan pemanfaatan arang sekam padi untuk media tanam dan persemaian padi dan pelatihan untuk pemanfaatan arang sekam padi untuk pupuk organik

Bahan dan alat yang digunakan dalam pengabdian masyarakat ini yaitu drum tertutup, kompor briket, korek api, panci, penumbuk (lumpang dan alu), limbah sekam padi, air, kanji, dan alat pencetak briket bioarang.

\section{HASIL DAN PEMBAHASAN}

Hasil dari program pelatihan ini, 2 kelompok tani Bimomartani memiliki pengetahuan, pemahaman dan ketrampilan dalam pemanfaatan limbah sekam padi sebagai bahan bakar alternatif (memasak), media tanam, dan pupuk organik.

Pertama, pelatihan tentang "Budaya Sadar Lingkungan dan Motivasi Berwirausaha". Hasil berupa pengetahuan dan pemahaman akan pemanfaatan limbah sekam padi yang dapat digunakan untuk membuka lapangan kerja/berwiraswasta mandiri atau penguatan perekonomian petani (bahan bakar alternatif, memasak, media tanam, pupuk organil dll). 




\section{Gambar 1. Mitra mendapatkan pelatihan budaya sadar lingkungan dan motivasi berwirausaha}

Kedua, pelatihan pembuatan briket bioarang dari sekam padi. Sebelum mencetak briket bioarang mitra bersama-sama dengan pendamping membuat lem kanji yang akan digunakan sebagi perekat pada pembuatan briket bioarang. Selanjutnya pembakaran sampah sekam padi secara pirolasi dengan menggunakan drum hingga menjadi arang sekam. Kemudian mitra bersama-sama dengan pendamping mencetak arang sekam yang sudah dicampur dengan lem kanji pada alat pencetak briket bioranag sehingga menghasilkan briket bioarang dan setelah terbentuk briket bioarang maka selanjutnya dikeringkan dan dapat digunakana sebagai bahan bakar alternatif untuk keperluan sehari-hari seperti memasak.

Hasil dari pelatihan ini adalah mitra memiliki pengetahuan dan ketrampilan membuat briket bioarang dari tahap pertama sampai tahap akhir pembuatan. Mitra mampu mengoperasionalkan alat cetak briket biorang sesuai prosedur kerjanya. Mitra juga mampu menghasilkan produk briket bioarang dalam pelatihan ini. 


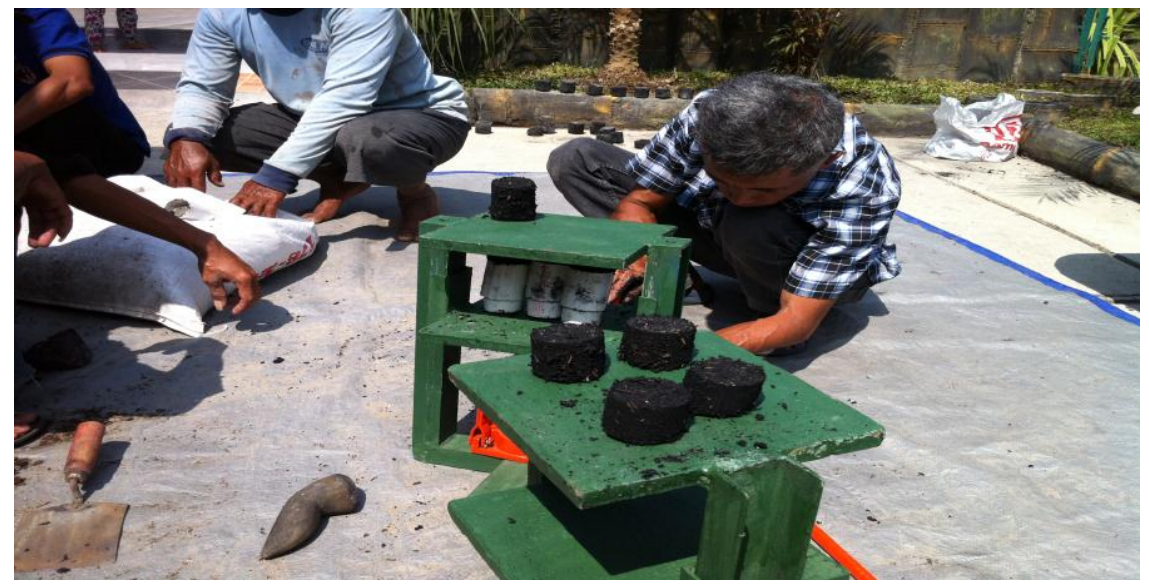

Gambar 2. Mitra membuat briket bioarang

Ketiga, Pelatihan pemanfaatan briket bioarang untuk keperluan memasak sehari hari di mulai dengan mitra diberikan pengetahuan cara menggunakan kompor briket diawali dari cara memasukkan briket bioarangnya sampai dengan cara membakar briket bioarangnya dan menggunakan kompornya,. Hasilnya briket bioarang digunakan sebagai bahan bakar alternatif / bahan bakar (bioenergi) untuk keperluan petani seperti memasak

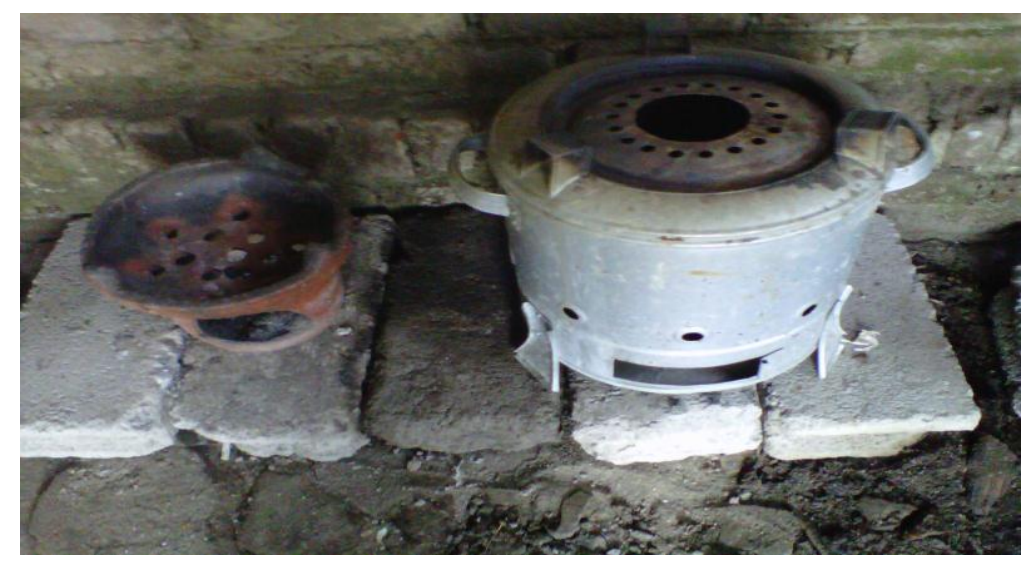

Gambar 3. Mitra menggunakan kompor briket bioarang

Keempat, pelatihan pemanfaatan arang sekam padi untuk media tanam dan pupuk organik padi yang diikuti mitra dengan mencampurkan arang sekam yang sudah kering dengan pupuk kandang sebagai media tanam dan pupuk organik. Arang sekam padi sebagai media tanam dan pupuk organik memiliki keuntungan padi yang dihasilkan berkualitas unggul, dari segi ekonomis harga jual padi organik lebih tinggi dari pada padi yang ditanam dengan pupuk kimia, biaya yang 
dikeluarkan jauh lebih sedikit sehingga keuntungan menjadi bertambah, dan kualitas tanah senantiasa terjaga.



Gambar 4. Arang sekam menjadi media tanam

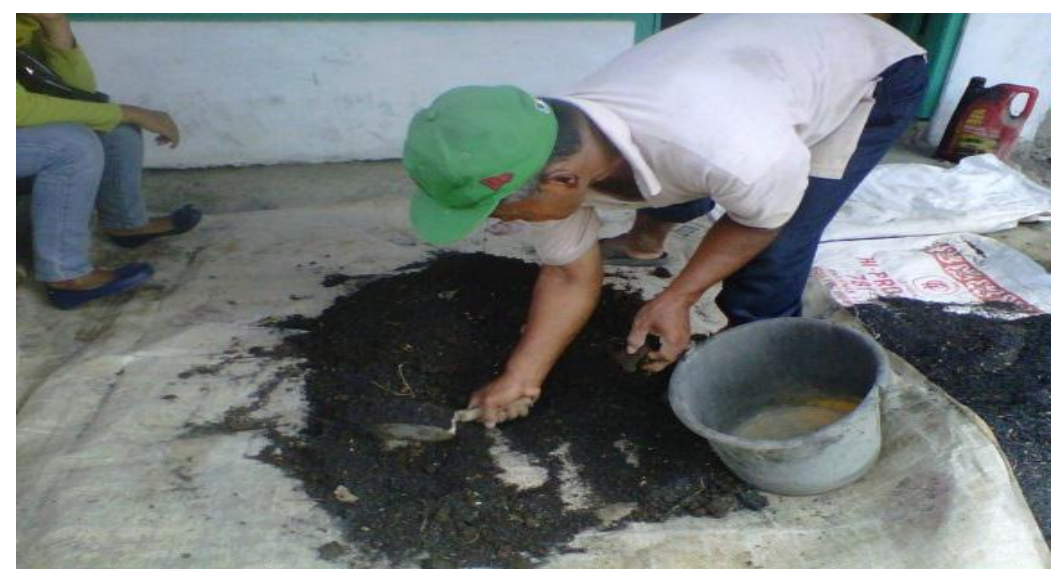

Gambar 5. Arang sekam menjadi pupuk organik

\section{DAMPAK}

Adanya peningkatan ilmu pengetahuan dan ketrampilan para petani serta perilaku sadar lingkungan dari pencemaran limbah sekam padi dengan pemanfaatan limbah sekam padi tersebut menjadi briket bioarang sekam, media tanam, dan pupuk organik dari sekam padi. Selain itu meminimalisasi pencemaran limbah sekam padi pada lingkungan persawahan dengan cara pemanfaatan limbah sekam padi menjadi briket bioarang sekam, media tanam, dan pupuk organik dari sekam padi. 


\section{KESIMPULAN DAN REKOMENDASI}

\section{Kesimpulan}

Kelompok tani Bimomartani memiliki pengetahuan, dan ketrampilan serta kemampuan untuk mengolah limbah sekam padi yang mencemari lingkungan sekitar pertanian menjadi briket bioarang, media tanam, ataupun pupuk organik. Pemanfaatan limbah sekam padi dapat mendukung perekonomian petani karena dapat mengurangi konsumsi bahan bakar fosil, mengurangi pembelian pupuk buatan, dan sekaligus meningkatkan produksi panen.

\section{Rekomendasi}

Produk hasil dari limbah sekam padi yang dihasilkan oleh mitra kelompok tani Bimomartani yaitu briket bioarang, media tanam dan pupuk organik mampu dimanfaatkan sebagai modal berwiarausaha mandiri, namun membutuhkan adanya menampung dan distributor maupun pasar dalam menjual hasil produk tersebut. Selain itu perlu perluasan cakupan kegiatan pelatihan pemanfaatan limbah sekam padi untuk meningkatkan motivasi berwirausaha misalnya pelatihan pengemasan produk maupun pelatihan pemasarannya.

\section{DAFTAR PUSTAKA}

Dinas Pertanian Kab./Kota, Provinsi D.I.Yogyakarta, 2010

Hambali. E, Mujdalipah. S, Tambunan. A. H, Pattiwiri. A. W, \& Hendroko. R. (2007. Teknologi bioenergi. Jakarta: AgroMedia Pustaka

Hambali. E, Mujdalipah. S, Tambunan. A. H, Pattiwiri. A. W, \& Hendroko. R. (2008). Teknologi Bioenergi Edisi Revisi. Jakarta: PT AgroMedia Pustaka

Hsu, H.W., dan Luh, B.S. (1980). Rice Hull. Dalam Rice Produck And Utilization. Editor: Bor Shiun Luh. New York: Avi Publishing Company Inc

Jumena. (2009). Pemanfaatan arang sekam padi sebagai pupuk organik [http://jumena.wordpress.com/2009/03/02/pemanfaatan-arang-sekam-padi-sebagai-pupukorganik/] diunduh pada 20 Januari 2015

Kurniawan. O, \& Marsono. (2008). Superkarbon bahan Bakar Alternatif. Jakarta Penebar Swadaya.

Kusmarwiyah R, Erni S. 2011. Pengaruh media tumbuh dan pupuk organik cair terhadap pertumbuhan dan hasil tanaman seledri (Apium graveolens L.).Crop Agro. 4 (2), 7-12.

Putri Al. 2008. Pengaruh media organik terhadap indeks mutu bibit cendana (Santalum album). Jurnal Pemuliaan Tanaman . 21 (1), 1-8.

Sukaryorini P, Arifin. 2007. Kajian pembentukan caudex Adenium obesum pada diversifikasi media tanam.Jurnal Pertanian Mapeta.10 (1), 31-41. 
Trisnadi, R. (2016). Manfaat Arang Sekam Untuk Pertanian. [http://disbunhut.probolinggokab.go.id/control/uploads/Arang\%20Sekam\%20Web\%202016. pdf] diunduh pada 25 Oktober 2016

Wuryaningsih, S dan Darliah. 1994. Pengaruh media sekam padi terhadap pertumbuhan tanaman hias pot spathiphyllum. Bul.Pen.Tan. Hias, 2 (2).119-129. 